\title{
After Decolonization, After Civil Rights: Chinua Achebe and James Baldwin
}

\author{
Bill Schwarz Queen Mary University of London
}

\begin{abstract}
The escalation of systematic, if random, violence in the contemporary world frames the concerns of the article, which seeks to read Baldwin for the present. It works by a measure of indirection, arriving at Baldwin after a detour which introduces Chinua Achebe. The Baldwin-Achebe relationship is familiar fare. However, here I explore not the shared congruence between their first novels, but rather focus on their later works, in which the reflexes of terror lie close to the surface. I use Achebe's final novel, Anthills of the Savanah, as a way into Baldwin's "difficult" last book, The Evidence of Things Not Seen, suggesting that both these works can speak directly to our own historical present. Both Baldwin and Achebe, I argue, chose to assume the role of witness to the evolving manifestations of catastrophe, which they came to believe enveloped the final years of their lives. In order to seek redemption they each determined to craft a prose-the product of a very particular historical conjuncture-which could bring out into the open the prevailing undercurrents of violence and terror.
\end{abstract}

Keywords: James Baldwin, Chinua Achebe, decolonization, U.S. civil rights, literature, terror, redemption

We have lost the twentieth century; are we bent on seeing that our children also lose the twenty-first? God forbid.

Chinua Achebe, $1983 .^{1}$

Fanaticism. The One Way, One Truth, One Life menace. The Terror that lives completely alone.

Chinua Achebe, $1993 .^{2}$

To counter "racial terror" we require "a ruthless cunning, an impenetrable style, and an ability to carry death, like a bluebird, on the shoulder."

James Baldwin, $1985 .^{3}$ 
We live in dangerous times. The perilous metaphysics of the war on terror seeps ever more deeply into the psychic organization of our everyday lives, given justification by the remorseless progression of daily barbarism inflicted on women, children, and men as they go about the otherwise uneventful business of their private lives. It is difficult to comprehend the enormity of the catastrophes which tear into human life and the logic of escalating violence which has come to define our age. We gasp out loud at the latest outrage, but the very speed by which one newsflash follows the next allows little scope for reflection, inviting in its place a chaotic clamour in which the mainspring of human agency itself seems to slip away and move beyond our reach. ${ }^{4}$

These mental reflexes, difficult though they are to grasp, must-in some wayinfiltrate our ways of reading. We may return to books we think we know well and be surprised by nuances we have barely noticed before. Familiar writers take on new hues, and on occasion come closer to the texture of our own lives, generating a feeling less of recognition than of disequilibrium. Old reading habits can calcify the very practice of reading, working to screen what history requires us to see. And then, as if from nowhere, by a curious conjunction of the personal and the political, our reading selves are hit by an air-pocket of turbulence, and we are jolted out of the familiar into the unfamiliar, such that we are defamiliarized from our own selves. In this lies the promise of reading.

More particularly, or more personally, this is what has happened with my engagement with James Baldwin. It feels like an epiphany. It is, of course, nothing of the sort, or at least not for others. All it does is to make us-or rather, mealive to the words on the page, which have (of course) been there all the while. I hope to demonstrate something of what this has entailed.

This occurred by way of a complex process of indirection. An important impetus lay in my reading of Chinua Achebe, and thence moving to Baldwin. I hope, here, to reconstruct something of this journey. I begin by recapitulating the received version (in Baldwin scholarship) of the relationship between Achebe and Baldwin, suggesting that this is an interpretation driven by an overinvestment in the salience of their early, or indeed of their first, novels. I then offer an overview of what I see as their respective writing trajectories. At this point I introduce Achebe's final novel, Anthills of the Savannah. And to conclude, I enlist Anthills of the Savannah to provide the groundings from which I approach Baldwin's last-difficult, contentious, impossible-book, The Evidence of Things Not Seen. In doing so, I hope to persuade readers that the affinity between Achebe and Baldwin can be read as productively from their final works as from their first. If we were to follow such an approach, I suggest, perhaps it could allow each of them to speak more profoundly to the predicament of our present.

\section{Achebe and Baldwin}

There exists a tiny sub-set of critical work on African fiction, or on AfroAmerican fiction, which devotes itself to the cross-cutting connections between 
the lives and the writings of Chinua Achebe and of James Baldwin. ${ }^{5}$ From this, and from the brief public testaments each made on behalf of the other, a known story has taken shape which turns on a few invariable elements. ${ }^{6}$

Both Achebe (1930-2013) in Nigeria, and Baldwin (1924-87) in the United States, were brought up in families dedicated to the virtues of what Simon Gikandi has identified as a patriarchal, peculiarly "Afro-Victorian," Christianity. These distinctive black sensibilities offered a means by which post-slave peoples, in the U.S., or the colonized, in West Africa, could imagine themselves becoming modern subjects, possessing the capacities associated with a sovereign location in the world. Their contradictory legacies inhabit the early fiction of both Achebe and Baldwin. This is especially so of their first novels: of Baldwin's Go Tell It On the Mountain (1953) and of Achebe's Things Fall Apart (1958). When Achebe first discovered Go Tell It On the Mountain in Nigeria at the end of the fifties, he determined that, at some point in the future, he would meet with Baldwin, later famously declaring "I knew here was a brother." ${ }^{8}$ For his part Baldwin, returning the compliment and equally famously, admitted that when he read Things Fall Apart he had "recognized everybody in it."

They weren't to meet in person, however, until April 1980, which was the occasion for these declarations. They found themselves in the Holiday Inn in Gainesville, Florida, at an African Literature Association conference where they were billed to discuss the question of an African aesthetic. Their meeting was overdetermined by a high degree of expectation on both sides, in which the history of empires-past informed their shared consciousness of the present. Achebe's initial greeting took the form of "Mr. Baldwin, I presume." ${ }^{0}$ And dramatizing his own regard for the weight of history, Baldwin remarked in relation to the presence of Achebe, in the strangely transcribed, or remembered, formulation which has been handed down to us: "I'll even say, of a somewhat unprecedented nature, my buddy whom I met yesterday, my brother whom I met yesterdaywho I have not seen in 400 years, it was never intended that we should meet."11

This, in outline, represents the distillation of the recognized narrative of Achebe-and-Baldwin. And, even though it doesn't stand as one of the stock refrains of the story, as it now circulates, we also know that when in 1987 Baldwin died he left Achebe his briefcase.

This way of narrating the story of their entwined lives attests to a warm, mutually respectful political-literary friendship for long deferred. Baldwin's words at Gainesville, believing their meeting to be symbolic of a momentary healing of centuries of enforced separation, gives this reading a forceful justificationalthough through his life Baldwin was more likely to emphasize the particularity of the black experience of the New World than to dwell on what black America shared with its West African roots. ${ }^{12}$ But to frame their 1980 encounter exclusively in terms of a predestined rendezvous between the young author of Go Tell It On the Mountain and the young author of Things Fall Apart works to conflate distinct historical times. It also prevents us from comprehending what at the conference they were charged to address: the politics of the aesthetic. 
I think it unlikely in the few days which Achebe and Baldwin spent together that they were particularly exercised by the novels which each of them had written some quarter of a century before. They would have been curious, of course, and their exchanges on their early fiction would have been of great interest to literary scholars. But one distinction they shared was their capacity for worldliness, to borrow from Edward Said. Throughout their lives, their writing derived its power from their tough, luminous engagement with the circumstances of their time. Writing became the conscious means for them both to situate themselves in the history of the present. With this in mind, I think it a disservice to each of them to interpret their intellectual dispositions in 1980 through the optic of their concerns of a generation before.

However "writing," in this context, remains a peculiarly abstract term. They were both alert to the vagaries and the possibilities of variant literary forms. After all, the official purpose of their meeting was to discuss the idea of an African aesthetic, which indicates that questions of form were immediately present. Each had made his literary reputation as a novelist; each was to discover, as history turned, that sometimes the novel-form was what they needed, and sometimes not. Their allegiance to the novel was never obvious, and even when it was, the form itself necessarily became a matter of dispute.

Chinua Achebe began publishing occasional stories in the early 1950s, while still a student. In 1954 he secured a job with the Nigerian Broadcasting Service, a key public institution in the making of the independent nation, and as a result moved to Lagos. His first four novels-Things Fall Apart (1958); No Longer at Ease (1960); Arrow of God (1964); and A Man of the People (1966) - not only coincided with independence, granted in October 1960, but also gave narrative form to the complex of popular feeling which, unevenly, accompanied the formal processes of decolonization. ${ }^{13}$ Although his prose remained studiously hard-headed when it came to assessing future prospects, and did nothing to conceal his apprehensions, this was nonetheless a historical moment in which it was possible to conceive of a political future for the mass of Nigeria's citizens.

Although the historical conditions in the U.S. were very different, and his allegiances to the political struggles he identified with were commonly perceived to be more indirect, Baldwin's early writing career was inseparable from what Martin Luther King Jr. at the time considered to be "the Third American Revolution." ${ }^{\prime 4}$ This was certainly true of the essays, culminating in The Fire Next Time which appeared in the cataclysmic year for black America of 1963. It was true, too, of his early novels: Go Tell It On the Mountain (1953); Giovanni's Room (1956); and Another Country (1962). Baldwin had an intimate knowledge, from the inside, of the mobilization of black America. Just as with the fiction of Achebe, it wasn't only in the prose that one can feel the resolve to build a new nation taking hold; what was imagined in the fiction also provided something of the temper of the emergent, collective insurrection. In his fiction Baldwin expended much labor in explaining the dangers of political innocence. His forebodings ran deep. But in the years which coincided with the publication of his 
first novels, he too could imagine-as much as Achebe-the realization of a political future.

When they met in Florida in 1980 a radically different historical conjuncture prevailed, about which each of them had been much preoccupied. In 1960, even amongst the officials of the British state, there existed a consensus that of all the African colonies Nigeria could claim to be the most developed, and hopes were high for the tranquil evolution of an orderly, constitutional polity. Those colonial officials who had been stationed in Nigeria showed no sign of panic when the game was up, leaving "quietly, amiably, often at night." 15 In the event, the collapse into systematic ethnic war and terror proved precipitate. The protracted racial descent in the United States-manifest most spectacularly in the assassinations; in the conflagration of the black ghettos; in the unleashing of state terror against those designated as subversives-can be marked in the desperate tenor of Baldwin's political sensibility, his prophetic voice shifting from Jeremiah to Job. ${ }^{16}$

Achebe, as we have seen, was in the habit of writing a work of fiction every couple of years, until the publication of A Man of the People in 1966. From then until his death in 2013 he only wrote one further novel, Anthills of the Savannah, which came out in 1987. He continued to publish short stories, poetry and writing for children but, with this exception, the cycle of novels came to an end.

With Baldwin, the shift in his commitment to the novel was less emphatic, but I think that something similar can be discerned. After Another Country in 1962 he published three further novels: Tell Me How Long The Train's Been Gone (1968); If Beale Street Could Talk (1974); and Just Above My Head (1979). It's not necessary to summon an aesthetic judgement in order to understand that these books occupy a different location-a different gravity-in Baldwin's oeuvre from his three earlier novels. At best, they can be described as "lesser known" works, a term coined in relation to Baldwin at a recent conference. ${ }^{17}$ To put things like this is not only indisputably true (the later work is less well known) but also suggests a measure of agnostic agility in addressing the question-or not-of Baldwin's decline in his writerly powers. Minimally, though, we might simply conclude that while there is a critical consensus about the earlier novels, the later works, at best, incite controversy or, at worst, silence.

These thoughts were prompted by my returning to Achebe's Anthills of the Savannah and by my experiencing something of the readerly disorientation which I described earlier. I realized the extent to which the novel occupies a distinct political and epistemological locus in Achebe's corpus. This realization prompted me to ponder again the nature of his authorial affiliation with Baldwin. For all the continuing mutual echoes between them, I couldn't see any strong formal symmetries between Anthills and any of Baldwin's last three novels. And yet, like many of Baldwin's readers, I had for long been troubled by his final work, published in 1985, The Evidence of Things Not Seen. This is an extended essay-not a novel, nor conceivably even fiction-which sets out to reconstruct the interlocking of competing mentalities which arose in the 
aftermath of the Atlanta child murders that took place between 1979 and 1981. Despite the crucial disjuncture in form it seemed to me that both texts share a significant preoccupation about form, turning on the question of how writing can operate in extremis. So by way of this hermeneutic ruse, I set out to read Baldwin's The Evidence of Things Not Seen through the lens of Anthills of the Savannah.

\section{Anthills of the Savannah}

Anthills of the Savannah inaugurates, in the novel-form, a conception of the postcolonial as tragedy. ${ }^{18}$ This is a large claim, which may or may not stand up to critical scrutiny, although-personally, at the moment-I'm persuaded by it. It isn't necessarily a reflection on the history of decolonization itself, although it could be. It's more a matter of how the histories of the end of the colonial empires came to be articulated in the imagination. My contention is that in Anthills the tragic voice assumes a new centrality in narrating the postcolonial, in the novel-form in particular, but with reverberations and parallels in other domains.

To propose such a thesis assumes, to a greater or lesser degree, that the preceding phases of the anti-colonial struggle, based on a presiding faith in the nationalist project, were conceived-in narrative terms-as a species of (revolutionary) romance, in which the ills generated by the colonial order would, in a single transcendent act of history, be righted.

This is a formal, narratological, proposition, not a historical one. It occurs most fully explicated in David Scott's important book, Conscripts of Modernity. ${ }^{19}$ In an assured work of exegesis, he contrasts the original (1938) edition of C. L. R. James's classic reconstruction of the Haitian Revolution of 1804, The Black Jacobins, to the revised version which James published in $1963 .{ }^{20}$ Nobody had done this partly because, insofar as anyone had even noticed them, the textual interpolations-the eight paragraphs-appeared to be minor and of no great significance. Scott believed otherwise. Drawing from Hayden White's Tropics of Discourse, he identified a profound recasting of the text, in these few paragraphs, from the imperatives of a vitalist, agency-inspired marxism (romance, in the sense indicated above) to a more sombre understanding of the "impossible" strategic and ethical choices which politics, including a revolutionary politics, presents. The figure of Toussaint L'Ouverture, the leader of the slave rebellion, personifies this impossible politics and is construed in James's imagination-notwithstanding his actual, documented, historical existence-as the authentic heir of his tragic literary forbears: "Prometheus, Hamlet, Lear, Phèdre, Ahab" ... and Toussaint. ${ }^{21}$ In foregrounding this tragic dimension, the 1963 edition does indeed differ from its 1938 precursor.

For this formal argument to be transformed into one which is historical it's necessary to alter tack from an exegetical reading to a looser, more capacious and fluid way of thinking, in which there is never an accomplished, single 
departure from one mode of thinking (romance) and arrival at another (tragedy). It's a story of false-starts, detours, missed connections, storms, doublingbacks and of a myriad of other fateful occurrences which waylay the traveler. But even this offers too intentionalist an interpretation, for it assumes that there exists from the outset a predetermined destination. Moreover, however much one voice (the tragic) moves to the center of things it never does so by obliterating the plurality of older voices (in this instance, the romantic): they come to co-exist in a new but unstable cacophony.

From this perspective, Anthills enacts an argument about the political limitations of the postcolonial novel. Decolonization in Nigeria marked, dramatically, not the conspicuous release of new collective energies, nor a significant advance in the materialization of popular sovereignty, but on the contrary the impasse of the nationalist project. Why invest much time and energy in writing a novel when you witness your compatriots dying on their feet, and when every time you venture onto the street you encounter-immediately, close up-human collapse? Anthills is a postcolonial novel which asks whether the novel-form itself can ever amount to an adequate critique of the postcolonial condition. It endeavors to bring the novel closer to the political realities of the postcolonial nation, and endeavors, too, to overcome its own textuality.

What could this mean, as no writing can ever overcome its own textuality without abolishing itself? This-textuality, a text, a sequence of words-is what a novel is, the means by which it exists in the world. But in Anthills the reader becomes aware that this is a novel which sets out to short-circuit the conventional novel-form by drawing on the (supposed) transcription of speeches and of state proclamations, and by resorting to an unusually didactic mode of storytelling. It's a novel which reproduces, at length, and seemingly verbatim, the political thoughts of its key protagonists. Achebe is intent on importing into the novel, untransformed, these disquisitions on the nature of postcolonial politics. And in so doing, he seems to call into questions the form and possibilities of the postcolonial novel, as a genre, itself. $^{22}$ If - to stretch things a littleAchebe can be said to have "founded" the postcolonial novel in 1958 with the publication of Things Fall Apart, was he, a generation later in Anthills, intent on announcing its demise?

These formal questions do indeed run through the novel. But Anthills of the Savannah also raises other questions of a different order, at a lower, more concrete level of abstraction.

In 2005 Chinua Achebe came to Queen Mary in London, where he gave a reading and answered questions from the audience. His driver had taken an age to arrive and the lecture-hall was packed to the rafters. When eventually Achebe appeared, the hall erupted, as if it were an old-school rock-concert. I, at the start of my career as a teacher of literature, was delegated to introduce him. I was nervous, certainly. Even so, in the end I thought I acquitted myself well enough and Achebe was generous. But in retrospect I feel more ashamed than anything for I failed to acknowledge the place of Biafra, and more particularly 
of the Biafran War, in the making of his-political, literary-life. I can see now that this was a grievous error, which resulted from an overly literary-academic perception of who Achebe was, and where his achievements lay.

We now possess Achebe's own account of the war, published in 2012, a year before he died: There Was a Country. A Personal History of Biafra. This conveys not only the degree to which Achebe himself was caught in the maelstrom of the war, but also the extent to which the war-on an African, continental scale-was historically decisive in dismantling the promise of decolonization and in instituting in its place a new regime of terror and corruption. Indeed, Achebe narrates the shift from a sensibility based on the promise of a human future to one a deal more despairing, driven by something like a tragic conception of the emergent postcolonial world. ${ }^{23}$

In There Was a Country Achebe describes what he calls the "pogroms" against the Igbo which began in May 1966, adding that they were "reminiscent of the Nazi policy of eradicating the Jews." ${ }^{24}$ As an Igbo he was active in the cause of Biafra. A son was born in 1967 and a daughter in 1970: he and his wife had to navigate many bloodied landscapes while caring for their infant and their infant-to-be. At times he served as an unofficial envoy for the fledgling nation, using his contacts abroad to seek international recognition of the desperate realities of the Biafran situation. The catastrophe entered his being. He concludes that during the course of the war, twenty per cent of the population of Biafra died, a total of three million people. This was largely due to the strategy of enforced starvation prosecuted by the Nigerian forces, and condoned by Britain, the United States, and by the leading democratic states of the day. Inevitably, the death-count remains a matter of fierce contention.

If we go back, from this standpoint, and consider the trajectory of Achebe's novel-writing, the degree to which Biafra came close to terminating Achebe's life as a novelist is apparent. However, we know that the destruction of Biafra did not-quite-bring to an end the succession of novels. After all, we have Anthills of the Savannah, and for all its plasticity and metafictional rumination it works, paradoxically, as a vindication of what, in times of emergency, the novel can do. The enormity of the disaster which Biafra represents did indeed lead Achebe to confront the question of the very possibility of the postcolonial novel. But for him this was an ethical rather than an epistemological matter. In Anthills, alongside questions about the possibility of the postcolonial novel, there exists a contrapuntal force-field organized around the question-not of whether the postcolonial novel is possible-but rather by the more ethically charged question of what the postcolonial novel can do. And in addressing this question, Achebe privileges the issue of language.

The opening chapter portrays the corruption of the state and, crucially, the collateral corruption of language. The scene is a cabinet meeting where fear possesses everyone. The passage is narrated from the point of view of Chris Oriko. Chris, as Commissioner for Information, is an agent of the governing apparatus, although he also believes himself to be apart from the network of 
power which is gathered around the political leader-who himself always appears in the eyes of his cabinet, and no doubt in his own, as Your Excellency. In the chapter-heading Chris is attributed the title of "First Witness," which is how he sees himself: as witness to the evolving destruction of his nation. But Chris is aware, or half aware, that the longer he remains part of the ruling elite the closer he comes to corrupting his own self. And thus he becomes witness not only to the fate of his nation but to his own downfall too. On the first page of the novel he admits to this incremental moral collapse. He apologizes to His Excellency, and then, cravenly, repeats his apology. A year previously, he reflects, he would have never done that, "without doing grave violence to myself." 25

Nothing is spoken as it is. Language itself becomes the means by which power operates, both the source and the consequence of political instrumentality. The jokes passed around the cabinet table highlight this state of affairs, while at the same time they work to confirm the mendacity of the spoken word. As His Excellency himself points out, Chris, as Commissioner for Information, "owns all the words in this country-newspapers, radio and television stations." He is, in the view of His Excellency, "Honourable Commissioner for Words." 26

Chris-even as he stands as witness to the depredations of political life-is inescapably enmeshed in the system of power which he reviles. Power is not the creature of the state, nor even of the leader-the figure who wields supreme authority-nor indeed of any identifiable human agency: yet it is total, or in this restricted sense totalitarian, so pervasive that very few can escape its remit. ${ }^{27}$ No-one who is party to it is safe. Chris dies a random, seemingly inconsequential, death. His Excellency meets a degraded end, notable more for the fact that it exemplifies a fittingly administrative rationale than it does the sadism which the killing demonstrated. Power in the novel is not a phenomenon which lies outside the central characters. It is omnipresent, intangible, decentered, existing beyond the will of any single individual. It is invested in the everyday, in the mundane, in the unnoticed clichés of daily speech, inseparable from language itself. All (or nearly all) are complicit. No-one, it transpires, has the power to "own" words. It is the words which own their speakers. As the leader of the rebellious Abazon delegation expressed it: "The story is our escort; without it we are blind. Does the blind man own his escort? No, neither do we the story; rather it is the story that owns us and directs us." 28

The corruption manifest in the state also invades, unnoticed, the rhythms of private life. In place of a civil society given meaning by a shared conviviality there appears a low-level, banal instrumentalism, suggesting that a psychic dissociation scars even the most intimate forms of sociability. Everyone, or nearly everyone, is complicit in the dismantling of the nation.

But where the corruption appears most invasive is when it enters the erotic and intimate. This is particularly so in the long scene, recounted twice through competing perspectives, of Beatrice's-Chris's girlfriend-visit to the 
countryside retreat of His Excellency, where she becomes part agent of her own corruption, and in part reduced to an object of barter. Chris's role in this is ambiguous. It's never made clear where his irresponsibility might lie, except through Beatrice's response. She believes that Chris, her lover, was complicit in the transaction, and the angrier she gets with him the more exposed and untenable his position becomes. These characters-Chris, Beatrice and their friend, Ikem-are as close as the novel gets to embodying heroic virtue, certainly amongst the conventionally leading protagonists. Yet all three find themselves drawn into a sensibility of radical indifference which, in other departments of their lives, they are pledged to subvert. To varying degrees they are the indirect agents of their own destruction.

The force of Achebe's prose lies less in the reconstruction of the acts of terror perpetrated by the agents of the state than in its capacity to convey, in Arendt's terms, how the domain of politics itself-where dialogic, public life happens-is undermined. And as the novel suggests, this destruction is carried over into the private lives of the principal protagonists, and this is where the tragedy is located.

There is a theatrical quality in the logic that determines the respective fates of Chris, Ikem, and Beatrice, and also in the operations of power which impinge on, and unhinge, their lives. The reader is told specifically in relation to His Excellency, specifically, about "Sam's sense of theatre." 29 Power itself is constituted as theatre, always on show, yet simultaneously out of reach and intangible. It is felt but never located. At times, there is something remorseless about this, the system of power working to its preconceived ends. At other moments the people themselves are given voice and the reader is presented with the dynamic of a vernacular theatrics. When the narrative moves from those men educated for authority, for whom doom is never far distant, to the popular classes the exercise of power becomes more contingent and fragile.

Indeed, in terms of Chris, Ikem, and Sam (although less so in the case of Beatrice) the force of fate is pronounced. Theatre, in this dimension, is the means by which the tragic properties of the novel are organized. The two protagonists designated as "witnesses" (Chris and Ikem) are both doomed to die a premature death as, indeed, is Sam. Chris, the first witness who recounts the opening scenes of the story, is already dead by the time we read the novel. ${ }^{30}$ The men die and the women survive. It is Beatrice who prophesies Chris's death as he travels deeper into Abazon (into a fictionalized rendering of Biafra). She knows that he is travelling "in his death." ${ }^{31}$ In terms of the popular (Abazon) fables which are also incorporated into the novel, alongside the administrative memoranda, the speeches and political theses, he becomes the tortoise (as Ikem has it), managing temporarily to outwit the leopard-his much stronger foe. But his fate is already sealed. There can be no escape. The deaths of Chris, Ikem, and Sam have been, the readers are told, "programmed in advance by an alienated history." 32 What is this but classical tragedy?

One way of approaching Anthills of the Savannah is to suggest that Achebe recruits the novel-form to introduce a specifically postcolonial invocation of the 
tragic. ${ }^{33}$ From the start, Achebe in his fiction had been drawn to a tragic sensibility. It was this, particularly, which provoked Wole Soyinka's hostility to Things Fall Apart. ${ }^{34}$ In Anthills, though, the tragic voice is more insistent, and has a deeper hold on the narrative. This is primarily a historical rather than a formal matter.

We can return to David Scott and to C. L. R. James's interpolations to the second edition of The Black Jacobins. These were crafted in 1963, just at the moment when the mental landscape of the postcolonial order was beginning to take shape. At this moment the principal means by which the world "after colonialism" was articulated, by those who struggled to bring it into being, was as a variant of revolutionary romance. This voice, for example, could be heard in Bandung in 1955, in the Paris Congress of Negro Writers and Artists the following year, and in the speeches and proclamations of any number of the new generation of nationalist leaders. It's not that this was the only way of imagining the end of colonial rule. There were plenty of alternative lonely, dissenting voices. However in what we might call the postcolonial conjuncture of the end of the fifties and the beginning of the sixties, brief though it was, these alternatives were just that: lonely and contrary, with relatively little capacity for animating actually-existing political forces. And-moreover-it took a rare political intelligence to suggest, in this historical time, that there was a quality intrinsic to the postcolonial epoch which could be identified as tragic.

If we follow Scott, C. L. R. James was one such voice. ${ }^{35}$ Yet persuasive as these readings may be, it is undeniably the case that these "emergent" sensibilities-to draw from Raymond Williams-in which the apprehensions of the postcolonial as tragedy were first incubated were never only tragic, to the exclusion of all else. The thinking of James, and perhaps Richard Wright too, even as it voiced the tragic predicament of their generation, remained imbricated in the imperatives of the revolutionary romance. Formally, this may seem an impossibility; historically, it was nothing of the sort.

This ambiguous location of the tragic in the mentalities of what I have called the-classic, heroic-postcolonial conjuncture is evident too in what is probably, now, the most widely read text of the period: Frantz Fanon's The Wretched of the Earth. David Scott cites it as the exemplification of the revolutionary romance. ${ }^{36}$ Robert Young, on the other hand, while contrasting two contemporaneous postcolonial texts-the rarely paired Wretched of the Earth and A House for Mr. Biswas-comments that "The first treats the humiliation of colonialism as tragedy, the second as farce." 37 In Wretched of the Earth, however, the tragic and the romantic coexist. When Fanon discusses the depredations of the present, the tragic voice is dominant, particularly when indicting the political failures of the postcolonial national bourgeoisie, culminating in what he calls-in uncharacteristically modulated prose- "tragic mishaps." 38 Yet for Fanon the transition from tragedy to romance can be effected through the politicization of the masses. As the struggle for freedom advances, the native "will have no more 
call for his fantasies." "After centuries of unreality," Fanon writes, "after having wallowed in the midst of the most outlandish phantoms, at long last the native, gun in hand, stands face to face with the only forces which contend for his life-the forces of colonialism." 39

This admixture of the tragic and the romantic underwrote much of the thinking inscribed in what I've termed here the postcolonial conjuncture, and this includes Achebe's early fiction. After the destruction of Biafra, Achebe's mood did not merely "darken." The tragic voice assumes a new location in his thought. In consequence, the founding categories of the anti-colonial romance demanded profound, serious renovation. It's this shift which Anthills signals, and it's not restricted to Achebe.

In Anthills there exist contrapuntal moments of potential redemption, counter-narratives which work to undercut the overriding imperatives of tragedy. These are neither indebted to classical tragedy, nor to Fanonian conceptions of revolutionary, anti-colonial praxis, "gun in hand." "Even in the darkest times," observes Arendt, "we have a right to expect some illumination." ${ }^{40}$ Three strands can be identified.

First, there exists the redeeming power of popular life, which is deeply associated with Abazon. Chris's final journey, on the road to Abazon, represents not only his attempted escape but so too his growing enlightenment. The further he moves away from the governing institutions of the state, immersing himself in the life of the people, the deeper is his knowledge of the nation. Commensurately his self-knowledge becomes more serious. This signals an inversion of Marlow's journey to the interior in Heart of Darkness. Enlightenment, here, thrives in darkness. Chris encounters a world of deeper collective responsibility.

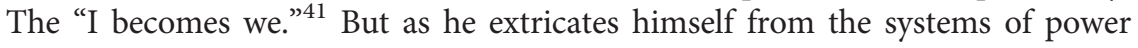
he moves closer to his death.

Second, Achebe is uncompromising in his belief in the potential emancipatory power of femininity itself. One imagines that Anthills of the Savannah is the work in which Achebe expressly re-stages his own encounter with feminism, or in the vocabulary of the time, with Women's Liberation. We can assume that Ikem's written thoughts on women's oppression are pretty much Achebe's. Beatrice, too, has much to learn: at the beginning she can't see that Elewa is offering her a call for women's solidarity. It is only by jettisoning her past that Beatrice can survive in the present. Beatrice's redemption turns, specifically, on the collectivity of women. She becomes the custodian of memory, her act of writing her diary working as an important means in her own remaking. When Chris and Ikem near their deaths, Beatrice takes on the role as witness for the future. As the feminine voices become more prominent, the narrative itself becomes increasingly dialogic.

Third, the novel is emphatic in its conviction that those who respect the integrity of narrative, who recognize the power of narrative, are those-and only those-capable of beholding the future. Central in this respect is the elderly 
leader of the delegation of Abazon. He has come to conclude, in his aged wisdom, that it is not the battle which is decisive, but the telling of the battle:

only the story can continue beyond the war and the warrior. It is the story that outlives the sound of war-drums and the exploits of brave fighters. It is the story ... that saves our progeny from blundering like blind beggars into the spikes of the cactus fence. The story is our escort; without it we are blind. Does the blind man own his escort? No, neither do we the story; rather it is the story that owns us and directs us. ${ }^{42}$

Thus it appears that ultimately Anthills is less about the impossibility of the novel as the medium for engaging with the postcolonial so much as an attempt to re-politicize the novel-form, such that it can contend with historic realities of the postcolonial epoch. In formal terms, Anthills is not conspicuously radical, although this is not to underestimate its structural complexities. It revives many of the properties for long associated with the novel, and demonstrates that while the novel can continually renew itself by becoming ever-more protean, this is the work of recuperation as much as it is innovation.

In a manner which conforms to Mikhail Bakhtin's conceptions of the novelform, Anthills recreates itself by incorporating into its constitutive structures the plurality of ("new") popular voices; popular laughter; the competing registers of non-standard English; the multiplicity of feminized voices; the poetic resources of folk legend; and, finally, politics. These strategic ploys represent the possibility of forging other ways of knowing. In so doing the novel frees itself from the sensibilities of radical indifference, and possesses the capacity to subvert the programmed process of an "alienated history" in which tragedy is generated. The novel itself becomes the tortoise, endeavoring to outwit the leopard: to outwit, that is, the collective internalization of debased narrative.

In his long speech the nameless leader of the Abazon delegation counsels his listeners, in the face of state terror, to "go on with your naming ceremonies." 43 And this is how Anthills closes. The ceremony is re-possessed by the women: by Beatrice, Elewa, and Agatha. In so doing Beatrice, particularly, recasts the locations of patriarchy. Elewa's daughter is born, becoming in a moment of feminine communion "the daughter of us all," born to the sound of women's tears and of women's laughter. ${ }^{44}$

Just as "the daughter of us all" is born, fatherless and in the face of adversity, so too is the postcolonial novel re-born, in the wake of the terrors of the postcolonial epoch. But the novel does not belong to us. "It is the story that owns us." Or as Achebe writes elsewhere:

Literature, whether handed down by word of mouth or in print, gives us a second handle on reality; enabling us to encounter in the safe manageable dimensions of make-believe the very same threats to integrity that may assail the psyche in real life; and at the same time providing through the self-discovery it imparts a veritable 
weapon for coping with these threats whether they are found within problematic selves or in the world around us. What better preparation can a people desire as they begin their journey into the strange, revolutionary world of modernization? ${ }^{45}$

\section{The Evidence of Things Not Seen}

In James Baldwin's writings the expressly tragic dimensions are not as pronounced. But the trajectory he follows has affinities with Achebe's, characterized most of all by his determination to get as close as he was able, as a writer, to the reflexes of terror which he believed were coming to dominate life in the United States. And like Achebe, he was less concerned with the acts of barbarism themselves, which cut into human lives, than with the banal quotidian mentalities in which terror is induced, and which touch us all.

Notwithstanding the specificities of local circumstance and local knowledge, and without collapsing the respective histories, the questions which confronted Baldwin in Atlanta converged with those which broke into Achebe's being in the aftermath of the Biafran War. What ethical imperatives predominate in a time of terror? What modes of writing are not only efficacious but possible? The fact that each of them was compelled to ask such questions, and the insistence with which they tracked the consequences of their apprehensions, make them peculiarly contemporary, if still dissonant, figures. This isn't to say that the more contemporary we perceive them to be, the more "like us" they become. This is not so. Whenever the living call upon the dead to speak to the present-and as we strain to catch what they say-they do so, implacably, on their own, uncanny, terms.

The Evidence of Things Not Seen, which concerns me here, was first published in 1985 and it proved to be the last book Baldwin wrote. It is, at one level, a work of commercial reportage, commissioned by Playboy. At the time Baldwin was living in France, as he had been for many years. His brief was to return to the U.S. and explore the Atlanta child murders which had occurred between 1979 and 1981. All those killed were African-Americans, and all but the last two of the murders were of children. It's still not clear which of the killings, or which of those reported to be missing, should be classified as constituting the phenomenon of the 'Atlanta Child Murders,' although it is certain that the figure well exceeded twenty. In June 1981 a local black resident of Atlanta, Wayne Williams, was arrested for the murders of the two adults for which, early the following year, he was found guilty. Although there existed widespread official and popular supposition that he must, additionally, have been responsible for the murders of the children, this was never legally substantiated at the time, and nor has it been since. Much remains unknown.

The assignment proved heart-breaking for Baldwin. It's little wonder that, in retracing the locations and meeting with the bereaved, the prose creaks and cracks. A missing child, he avers-"For you, or for me"- "distorts, totally, the universe. ${ }^{36}$ The conventions of documentary reportage couldn't even begin to 
work; to place himself beyond the story as an observer untouched by what confronted him was, in political and narratological terms, an impossibility. "I have never, in all my journeys, felt more of an interloper, a stranger, than I felt in Atlanta, in connection with this case, and I sometimes cursed the editor whose brainstorm this has been." 47

Twenty years earlier Baldwin had opened The Fire Next Time with a short essay "My Dungeon Shook," which took the form, as the subtitle explained, of a "Letter to My Nephew on the Hundredth Anniversary of the Emancipation." His nephew, named James after him, was then a young teenager, the same age as the murdered Atlanta children two decades later. The letter represented both an intimate (private) counsel to his nephew, growing up in Harlem with adulthood in his sights, and a (public) warning to America, a century after emancipation, that the perils of race were intensifying, ready to explode. Baldwin works from the premise that James's grandfather-his own father-was "defeated before he died," and that the urgent mission for the new generations was to ensure that this fate was not to be theirs. James's generation did not need the unbending, Old Testament "holiness" of their grandparents. Those in the North had never known what it was to live on the plantations of the South, their forebears having migrated to the "cities of destruction." This migration brought with it new possibilities, as well as new dangers. "One can be, indeed one must strive to become, tough and philosophical concerning destruction and death." "Tough" and "philosophical:" these are the qualities which, for Baldwin, survival demanded. So too is "love"-which in the Baldwin lexicon was never far removed from a "tough" and "philosophical" way of being, pace Doris Day and Gary Cooper. "And now you must survive," he tells his nephew, "because we love you, and for the sake of your children and your children's children." ${ }^{8}$

This was Baldwin in 1963. By the time he wrote The Evidence of Things Not Seen the terrors he apprehended in The Fire Next Time had become, as he conceived things, the given, everyday reality, not only in Atlanta but throughout the United States. His nephew James's children, bar a throw of the dice, could easily have been counted among those murdered. Survival, in his vision, was becoming ever-more precarious. The entire social world seemed to be conspiring to undermine the very possibilities of imagining a future, "for the sake of your children and your children's children."

When Baldwin travelled to Atlanta he knew well enough that he was entering a historical emergency. The "terror" he confronted did not so much "alter the climate of Atlanta as reveal, or, as it were, epiphanize it." 49 The city, moreover, functioned as the microcosm of the larger nation. The institutions of the law resembled nothing less than "a visceral Roman circus." Atlanta appeared to Baldwin to have been transmogrified into "a kind of grotesque Disneyland," where he felt akin to being "trapped in the slave quarters of the Southern gothic romance." ${ }^{51}$ In the heat of the day, dark, disturbed, and unforgiving America stalked the streets, enabling things normally unseen to enter the field of collective vision. The "weight" of "racial terror," commonly out of sight of the 
national media, was-in the emergency which possessed the city-inescapably proximate, day by day, hour by hour, pressing in on every life. ${ }^{52}$ The commission from Playboy, strangely, provided Baldwin the opportunity to produce a symptomatic reading of race in America, through the lens of Atlanta.

However, this wasn't only a matter of location. It was a matter of historical time too. The crisis in Atlanta coincided with the first inauguration of president Ronald Reagan, a strategic moment in what Baldwin, amongst others, took to represent the consolidation of a new, emergent neoconservative order. He felt keenly the extent to which erstwhile political allies, including many whom Baldwin had once "trusted ... with my life" - "yesterday's Liberals, the Negro's friends" - had jumped ship and affiliated to the new forces of conservatism. ${ }^{53}$ More particularly he sensed the emergence of a national psychosis in which perceived enemies, within and without, were incessantly denounced in a shrill, relentlessly phantasmagoric public chorus.

The cowardice of this time and place-this era-is nowhere more clearly revealed than in the perpetual attempt to make the public and social disaster the result, or the issue, of a single demented creature or, perhaps, half a dozen such creatures, who have, quite incomprehensibly, gone off their rockers and who must be murdered or locked up. Thus, for example, these present days, to describe a person, or group of persons, as leftists, guerrillas, or terrorists is to dismiss their claim to human attention. We are not compelled to think of them at all anymore, except as vermin that must be destroyed. ${ }^{54}$

The defeat of the aspirations which had given life to King's "Third American Revolution" ran deep. This experience of defeat dominated the latter decades of Baldwin's public life. His fears for America quickened, and in an increasingly hostile environment they were uttered at an ever-higher pitch.

The title of The Fire Next Time came from an old spiritual.

God gave Noah the rainbow sign.

No more water, the fire next time. ${ }^{55}$

For Baldwin, Atlanta and the nation it represented embodied this truth. The "fire next time" had descended, and had recast, in "the urgency of the moment," the inner life of America. ${ }^{56}$

In 2007 the writer Caryl Phillips delivered a lecture on Baldwin in which he mentioned in passing The Evidence of Things Not Seen. He was not impressed by the virtue of the book, finding that it seemed

to have been, from the beginning, badly conceived. As it proceeds it feels increasingly padded with irrelevant autobiographical asides which continually lead the reader away from, rather than towards, the subject matter under consideration. ${ }^{57}$

One can see what Phillips means. It has little of the formal elegance, or precision, of The Fire Next Time, and it doesn't read like the model for the "well-constructed 
essay." But I wonder whether such rectilinear criteria miss the point, obscuring exactly what Baldwin was charged to illuminate: the unseen infiltration of the reflexes of terror into the psyche of the nation. ${ }^{58}$

In writing The Evidence of Things Not Seen Baldwin was inhabiting a "distorted" universe, in which his deepest nightmares offered the truest alibi for the reality that Atlanta, and America, presented. He was forced to confront "a rupture in the order of things." 59 Like Achebe in Anthills, Baldwin was preoccupied with the normative properties of a terror which works silently, administratively - a terror which refuses to draw attention to itself-and in which, through the very words we employ, we are all implicated.

In the book Baldwin determined to depict not merely a social or political emergency, but a semiotic collapse, or a semiotic emergency, in which language and narrative were themselves at stake. ${ }^{60} \mathrm{He}$ identifies a "space of confusion in which the word is not suited to the action, nor intended to be-in which action is not suited to the word, nor intended to be." The resulting "chaos" he likens to a plague. (Thomas Mann's Death in Venice lies near the surface of Baldwin's text.) And, as much as in Achebe's prose, the "chaos" itself-the duplicity underwriting the relation between signifier and signified-derives from an overarching "moral vacuum." This he describes as a general, American, state of affairs. ${ }^{61}$ In the chaos of this collapse, the instrumental languages of the state, dedicated to propagating the virtues of political and social "hygiene," exist at one remove from the sensibilities of the general populace, of the multitude. ${ }^{62}$ "The world's definitions are one thing and the life one actually lives is quite another."63 "Official language" is equated with "official indifference." position by the authorities that Wayne Williams, in being found guilty on the two murder charges, was thus guilty of the full roster of killings stands as a menacing symptom of the malaise of the polity. Such short-circuiting of thought "establishes a precedent, a precedent that may lead us, with our consent, to the barbed wire and the gas oven." 65

This returns us, above all, to the question of language.

Speech and language, however ceremonious, complex, and convoluted, are a way of revealing one's nakedness; and this revelation is, really, our only human hope. But this hope is strangled if one, or both of us, is lying. ${ }^{66}$

For Achebe, I argued, notwithstanding the force of his investments in consideration of form, the question of how the novel-form itself was to be judged was of secondary significance. Issues of ethics predominated. The same is true of Baldwin. In the body of his writings, the non-fiction and the fiction were always "interpenetrative genres." ${ }^{27}$ His essays work by the interweaving of stories, and the autobiographical mode slides across the fiction and the non-fiction. Generally, what Phillips identifies as Baldwin's “autobiographical asides” are not asides at all. They work as the founding premise of all his writing. The choice between the novel and the essay never seemed to have been ultimate, nor to have been a 
matter of form alone. ${ }^{68}$ As with Achebe, the priority was to discover the means by which language could be mobilized, and in doing so freed from the enveloping structures of innocence and indifference, by any means necessary. Such writing could take many forms, not all of which were well received by Baldwin's more self-consciously scholastic readership. As the epigraph at the start of this essay signals, he relied upon an appropriately "distorting," metaphorical image to indicate that writing which works to subvert indifference does so because of its "ability to carry death, like a bluebird, on the shoulder."

As we've seen, for Achebe, memory offered a vital resource in establishing human sovereignty free from the impress of indifference. Women worked preeminently as the bearers of memory, evident crucially in the strategic positioning of Beatrice's diary in the architecture of the narrative of Anthills.

Baldwin, for his part, was not so sure. His commitments to memory remained equivocal. His equivocation is emphasized from the very opening sentences of Evidence of Things Not Seen:

after all, what I remembered-or imagined myself to remember-of my life in America ... was terror ... what I am trying to suggest by what one imagines oneself to be able to remember is that terror cannot be remembered. One blots it out ... One invents, or creates, a personality ... Beneath this accumulation ... sleeps or hopes to sleep, that terror which the memory repudiates.

He continues:

Yet, what the memory repudiates controls the human being. What one does not remember dictates who one loves or fails to love ... What one does not remember is the serpent in the garden of one's dreams.

But how, he asks, does this concern the murdered children of Atlanta?

It has something to do with the fact that no one wishes to be plunged, head down, in the torrent of what he does not remember and does not wish to remember. It has something to do with the fact that we all came here as candidates for the slaughter of the innocents. It has something to do with the fact that all survivors, however they accommodate or fail to remember it, bear the inexorable guilt of the survivor. It has something to do, in my own case, with having once been a Black child in a White country.

And he concludes:

My memory stammers: but my soul is witness. ${ }^{69}$

It's clear that this privileges the dark and troubling dimensions of memory, "the serpent in the garden of one's dreams." But we can't be certain where it leaves us. Baldwin was skeptical of any attempt to establish an easy equivalence between memory and salvation, and he was fierce in distancing himself from the abstract, meaningless injunction "to remember." Indeed memory signified for 
him less a vehicle for salvation than a conspicuous symptom of a contemporary pathology. Yet at the same time his conception of "things not seen" draws attention to those pasts which have, in social and interior lives, as a consequence of much political and psychic work, been repressed from conscious life. While memory "stammers" - as indeed it does-the "soul" appears to be the infallible partner of a fallible "memory." Maybe so. It all depends on what Baldwin means by "memory" and by "soul." Often, when he despaired of contemporary sensibilities, as he often did, he would find himself drawn back to the New Testament. And so he does here. The first epigraph for the book, taken from St. Paul (alongside William Blake: "A dog starv'd at his master's gate/Predicts the ruin of the state"), introduces the idea of "faith" as the substance of things hoped for:

Faith is substance of things hoped for, the evidence of things not seen.

Faith as the sign of "things hoped for" which cannot yet be, but which nonetheless needs to be nurtured "for the sake of your children and your children's children;" and faith in the future as the means by which broken, repressed memories may yet be rehabilitated: these are the watchwords of The Evidence of Things Not Seen.

There is however a missing term, which takes us back to the necessity for narrative: my soul as witness.

The authority of the witness is a predominating theme for Achebe in Anthills of the Savannah. ${ }^{70}$ Chris and Ikem set out as the self-styled witnesses to the fate of their country, and indeed to their own doomed futures. But, as the reader quickly discovers, by the time the novel opens they have already been condemned to die. Gradually, with much hesitancy on her part, the role of witness is accorded to Beatrice. This redistribution of moral responsibility in turn allows Elewa's new-born daughter to become "the daughter of us all." To witness, for Achebe, represents the means to maintain faith in the future.

In The Evidence of Things Not Seen a similar emphasis on witnessing is active, and the integrity of the witness is equally valorized. As with the fictional Chris and Ikem, Baldwin discovers that in Atlanta he himself turns out to be the unreliable witness; he is obliged to cede the responsibility of witnessing to others. When he meets one of the grieving mothers, Camille Bell, he admits that "I could not interview her because I simply did not know what to say to the mother of a murdered child, still less what to ask. I was certain that some kind of ghoulish curiosity was in my eyes and in my voice. I, mainly, listened."71 On occasion he loses his power of speech. ${ }^{72}$ He recognizes that he can only ever be "a partial witness." 73 In the event, in Baldwin's text, Camille Bell is established as the principal witness, adopting-or half adopting — the moral role which Baldwin was unable himself to shoulder. She fought the "official indifference" of the authorities, in the name of the dead children and of their surviving relatives. ${ }^{74}$ To do so, she had on occasion to employ "a caustic tongue." 
Even so, her "testimony" carried "great authority."75 Baldwin's gift, as author, was his ability to offer others a public voice, pluralizing the act of witnessing.

The idea of the witness in the later writings of Achebe and Baldwin owes a debt, I imagine, to the Christian, Afro-Victorian sensibilities in which they were both reared. So too does the ethical weight they accorded to their roles as writers, themselves witness to the depredations of the present. But I think that this can be put both more concretely and more strongly. Although they were innovatory writers, neither embraced the avant-garde. They were too preoccupied by the everyday instrumental corruption of language, and sought to find a means by which linguistic integrity could be restored within the polity. They wished to overcome what Baldwin identified as the semiotic "chaos" which prevailed and to rebuild the relations between words spoken and political practice, between signifier and signified. Only if this were achieved, they implied, could language be divested of its complicity with terror. Such emphases are not common today. They derived from a particular history, which is not ours. But in this they both perceived, in Baldwin's words, "our only human hope."

\section{Acknowledgements}

Thanks to Robert Reid-Pharr who opened the later Baldwin for me, and who first read Baldwin for a "poetics of terror" in his essay "Rendezvous with Life. Reading Early and Late Baldwin" in Cora Kaplan and Bill Schwarz (eds.), James Baldwin. America and Beyond (University of Michigan Press, 2011). Thanks also to Javed Majeed who did much the same for the later Achebe; and to Justin A. Joyce, Cora Kaplan, Leah Mirakhor, and Keith Mitchell.

\section{Notes}

1 Chinua Achebe, The Trouble with Nigeria (Enugu, Nigeria, Fourth Dimension Publishers, 1983), p. 4.

2 Chinua Achebe, "The Education of a British-Protected Child," (1993) in The Education of a British-Protected Child (London, Penguin, 2011; first published 2009), p. 5.

3 James Baldwin, The Evidence of Things Not Seen (New York, Henry Holt, 1995; first published 1985), p. 79.

4 There is a growing literature addressing these issues: I've always been much moved by Stanley Cohen, States of Denial: Knowing About Atrocities and Suffering (Cambridge, Polity, 2000).

5 Particularly, Ernest A. Champion, Mr. Baldwin, I Presume (Lanham, Maryland, University Press of America, 1995); and Eleanor W. Traylor, "James Baldwin and Chinua Achebe. Transgressing Official Vocabularies," in Cora Kaplan and Bill Schwarz (eds.), James Baldwin: America and Beyond (Ann Arbor, University of Michigan Press, 2011).

6 Chinua Achebe, "Postscript. James Baldwin (1924-87)," (1988) in Hopes and Impediments: Selected Essays, 1965-87 (Oxford, Heinemann, 1988); and Dorothy Randall-Tsuruta, "In Dialogue to Define Aesthetics: James Baldwin and Chinua 
Achebe," in Fred L. Stanley and Louis H. Pratt (eds.), Conversations with James Baldwin (Jackson, University Press of Mississippi, 1989).

7 Simon Gikandi, "Afro-Victorian Worlds," in Martin Hewitt (ed.), The Victorian World (Abingdon, Routledge, 2012).

8 Randall-Tsuruta, "In Dialogue to Define Aesthetics," p. 211.

9 Ibid., p. 211.

10 Achebe, "Postscript," p. 119.

11 Randall-Tsuruta, "In Dialogue to Define Aesthetics," p. 211.

12 Most forcefully in his commentary on the First Negro and Artists Congress in Paris in 1956; James Baldwin, "Princes and Powers," (1957) in Nobody Knows My Name. More Notes of a Native Son (New York, Dell, 1986).

13 This episode of his life can be followed in the early chapters of Chinua Achebe, There Was a Country. A Personal History of Biafra (London, Penguin, 2013; first published 2012); and Simon Gikandi, "Fifty Years of Things Fall Apart," Wasafiri 24:3 (2009). Yet even when he felt a justifiable degree of hopefulness, he was less sure about his investments in national politics. As he comments retrospectively: "Nigerian nationality was for me and my generation an acquired taste-like cheese. Or better still, like ballroom dancing," in "What is Nigeria to Me?" (2008) in British-Protected Child, p. 39.

14 Martin Luther King Jr., “The Negro Revolution," in Why We Can't Wait (New York, Signet, 2000, first published 1963), p. 1.

15 Achebe, There Was a Country, p. 48.

16 As they were speaking in Florida, an irate, threatening racist hi-jacked the a microphone, bringing terror close to home. For their responses: Achebe, "Postscript," p. 120; Randall-Tsuruta, "In Dialogue to Define Aesthetics," p. 216; and Achebe, BritishProtected Child, p. 66.

17 "James Baldwin: Transatlantic Commuter," Université Paul-Valéry, Montpellier 3: 5-7 June 2014. This was coordinated with spirit and an acute sense of the politics of the present by D. Quentin Miller and Claudine Raynaud.

18 C. L. Innes believes-although this is not exactly the same point-that Anthills recounts a "tragic history," Chinua Achebe (Cambridge, Cambridge University Press, 1992), p. 82.

19 David Scott, Conscripts of Modernity. The Tragedy of Postcolonial Enlightenment (Durham, Duke University Press, 2004). This is usefully read alongside Susan BuckMorss, Hegel, Haiti and Universal History (Pittsburgh, University of Pittsburgh Press, 2009).

20 C. L. R. James, The Black Jacobins. Toussaint L'Ouverture and the San Domingo Revolution (London, Allison and Busby, 1991).

21 James, Black Jacobins, p. 291.

22 This paragraph relies on Javed Majeed.

23 For contemporaneous accounts, Chinua Achebe, "The African Writer and the Biafran Cause," first delivered as a paper to Makerere University, Uganda, 1968; and his "In Reply to Margery Perham," first published in The Times, 19 September 1968: both reproduced in Achebe, Morning Yet on Creation Day (London, Heinemann, 1975).

24 Achebe, There Was a Country, p. 30 (where Achebe endorses the use of the term "pogrom" employed by the influential Observer journalist, Colin Legum), pp. 118 and 137. In his "Reply to Margery Perham" he calls the killings of the Igbo a "genocide," p. 85.

25 Chinua Achebe, Anthills of the Savannah (London, Picador, 1988), p. 1. 
26 Ibid., pp. 6-7.

27 This "unlimited, unmonitored wild zone of power" is, according to Susan BuckMorss, "a potential of every state that claims sovereign power," Thinking Past Terror. Islamism and Critical Theory on the Left (London, Verso, 2006), p. 31.

28 Achebe, Anthills, p. 124.

29 Ibid., p. 50.

30 Simon Gikandi, Reading Chinua Achebe (London, James Currey, 1991), p. 127.

31 Achebe, Anthills, p. 195.

32 Ibid., p. 220.

33 For an anticipation, see Achebe's non-fictional account of Nigeria's experience of the postcolonial: "Preface" to his Morning Yet on Creation Day, p. xiii.

34 Gikandi, Reading Chinua Achebe, p. 26. The tragedy is explicit from the beginning of the novel: Chinua Achebe, Things Fall Apart (London, Heinemann, 1986), p. 7. And see Wole Soyinka, Climate of Fear. The Reith Lectures 2004 (London, Profile, 2004).

35 So too Richard Wright: Bill Schwarz, "Black America and the Overthrow of the European Colonial Order. The Tragic Voice of Richard Wright," in Ruth Craggs and Claire Wintle (eds.), Cultures of Decolonisation (Manchester, Manchester University Press, forthcoming). As Wright indicated in his 1957 analysis of what he called the "Post-Mortem Terror," this was "a state of mind of newly freed colonial peoples who feel that they will be resubjugated; that they are abandoned, that no new house of the heart is as yet made for them to enter. They know that they do not possess the necessary tools and arms to guarantee their freedom. Hence, their terror in freedom, their anxiety right after their liberation, is greater than when under the dominance of the superior Western power," White Man, Listen! in Richard Wright, Black Power. Three Books from Exile. Black Power; The Color Curtain; and White Man, Listen! (New York, HarperPerennial, 2008), p. 683.

36 Stuart Hall and David Scott, "In Conversation," Bomb 90 (2005).

37 Robert J. C. Young, "World Literature and Postcolonialism" in Theo D'haen, David Damrosch and Djelal Kadir (eds.), The Routledge Companion to World Literature (Abingdon, Routledge, 2011), p. 219.

38 Frantz Fanon, The Wretched of the Earth (Hardmonsworth, Penguin, 1971; first published 1961), p. 119.

39 Ibid., pp. 44-5.

40 Hannah Arendt, Men in Dark Times (New York, Harcourt, Brace and World, 1968), p. ix.

41 Achebe, Anthills, p. 191.

42 Ibid., p. 124.

43 Ibid., p. 122.

44 Ibid., p. 228.

45 Chinua Achebe, "What Has Literature Got To Do With It?" (1986) in Hopes and Impediments, p. 117.

46 Baldwin, Evidence of Things Not Seen, p. 49.

47 Ibid., p. 55.

48 James Baldwin, The Fire Next Time (London, Penguin 1990, first published 1963), pp. 13-15.

49 Baldwin, Evidence of Things Not Seen, p. 74.

50 Ibid., p. 1.

51 Ibid., pp. 11 and 109.

52 Ibid., p. 78.

53 Ibid., p. 79. 
54 Ibid., pp. 72-3. Baldwin's sense of the direction in which history was moving was, in this respect, acute. This wasn't only because of his experience of racial subordination in his home nation. It may also have been due to the fact that he had already witnessed, at close quarters, a comparable collapse in public life earlier in his life. He had been living in Paris just prior to, and just after, the massacre of scores of Algerians in the centre of the city in October 1961. He speedily grew acquainted with the grisly mechanics of state retribution toward those deemed unworthy of "human attention," the effects of which he experienced for himself on his return to Paris in the aftermath of the slaughter. He had been shocked, too, by the unconcern-the indifference-of the native Parisians on their café terraces as, in front of their very eyes, a vengeful history was enacted. Kaplan and Schwarz, "Baldwin. America and Beyond," pp. 15-16; and Jim House and Neil MacMaster, Paris 1961: Algerians, State Terror, and Memory (Oxford, Oxford University Press, 2006).

55 Baldwin, The Fire Next Time, p. 89.

56 I draw from Martin Luther King's extraordinary "Letter from Birmingham Jail" (1963), in which he indicts political moderates for being in thrall to a "tragic misconception of time": King, Why We Can't Wait, pp. 78 and 74.

57 Caryl Phillips, "James Baldwin. The Price of the Ticket," in Colour Me English: Reflections on Migration and Belonging (London, Harvill Secker, London, 2011), pp. 244-5.

58 This is exactly Reid-Pharr's point in "Rendezvous with Life. Reading Early and Late Baldwin," in Cora Kaplan and Bill Schwarz (eds.), James Baldwin: America and Beyond (Ann Arbor, University of Michigan Press, 2011), pp. 126-38.

59 Gilles Deleuze and Félix Guattari, Kafka. Towards a Minor Literature (Minneapolis, University of Minnesota Press, 1986), p. 28. This was one of the constitutive features of what they identified as "minor," or subaltern, literature, which disrupted the hold of prescriptive, literary form. When they go on to observe that a "minor" literature is not drawn from a "minor" language, but rather from "that which a minority constructs within a major language," (p. 16), this is particularly relevant for the case of Baldwin. See especially James Baldwin, "If Black Isn't a Language, Then Tell Me, What Is?," (1979) in Toni Morrison (ed.), Collected Essays (New York, Library of America, 1998): "a language comes into existence by means of a brutal necessity, and the rules of that language are dictated by what the language must convey," p. 783.

60 "No other country," wrote Baldwin in his last essay, "has ever made so successful and glamorous a romance out of genocide and slavery," "Here Be Dragons," in The Price of the Ticket. Collected Non-Fiction, 1948-1985 (London, Michael Joseph, 1985), p. 678; emphasis added.

61 Baldwin, Evidence of Things Not Seen, pp. 41-2.

62 Ibid., p. 2.

63 Ibid., p. 86.

64 Ibid., pp. 65 and 62.

65 Ibid., p. 98.

66 Ibid., p. 43.

67 Kaplan and Schwarz, "Baldwin. America and Beyond," p. 22.

68 There have been attempts to fictionalize the Atlanta phenomenon. For one which originated from what we might understand to be a Baldwin orbit, Toni Cade Bambara, These Bones Are Not My Child (London, Women's Press, 2001; first published 1999). Bambara believed that The Evidence of Things Not Seen was too much an isolated 
intervention. "Had it been a voice in the chorus and not out there alone" it would have been more influential, p. 666. As the acknowledgements reveal, Baldwin and Bambara shared a network of friends. The manuscript was prepared for publication, after Bambara had died, by Toni Morrison. And see too Tayari Jones, Leaving Atlanta (New York, Warner Books, 2002).

69 Baldwin, Evidence of Things Not Seen, pp. xiii-xv.

70 The concept of the witness powerfully underscores the epistemology of subsequent truth and reconciliation inquiries. Thanks to Catherine Hall for reminding me of this important point.

71 Baldwin, Evidence of Things Not Seen, p. 54.

72 Ibid., p. 80.

73 Ibid., p. 61.

74 Ibid., p. 54.

75 Ibid., p. 55.

\section{Works Cited}

Achebe, Chinua, "The African Writer and the Biafran Cause," in Morning Yet on Creation Day (London, Heinemann, 1975), pp. 78-84.

"In Reply to Margery Perham," in Morning Yet on Creation Day (London, Heinemann, 1975), pp. 85-6.

14. "Preface", to Morning Yet on Creation Day (London, Heinemann, 1975), pp. 13-

The Trouble with Nigeria (Enugu, Nigeria, Fourth Dimension Publishers, 1983).

Anthills of the Savannah (London, Picador, 1988).

"Postscript. James Baldwin (1924-87)," in Hopes and Impediments: Selected Essays, 1965-1987 (Oxford, Heinemann, 1988), pp. 118-21.

"What Has Literature Got To Do With It?," in Hopes and Impediments: Selected

Essays, 1965-1987 (Oxford, Heinemann, 1988), pp. 106-17.

"The Education of a British-Protected Child," in The Education of a British-

Protected Child (New York, Knopf, 2009), pp. 3-24.

- The Education of a British-Protected Child (New York, Knopf, 2009).

"What is Nigeria to Me?," in The Education of a British-Protected Child (New

York, Knopf, 2009), pp. 39-46.

There Was a Country: A Personal History of Biafra (London, Penguin, 2013).

Arendt, Hannah, Men in Dark Times (New York, Harcourt, Brace and World, 1968).

Baldwin, James, "Here Be Dragons," in The Price of the Ticket. Collected Non-Fiction, 1948-85 (London, Michael Joseph, 1985), pp. 677-90.

The Fire Next Time (London, Penguin, 1990).

"Princes and Powers," (1957) in Nobody Knows My Name: More Notes of a

Native Son (New York, Vintage, 1993), pp. 13-55.

The Evidence of Things Not Seen (New York, Henry Holt, 1995).

"If Black Isn't a Language, Then Tell Me, What Is?," in Toni Morrison (ed.),

Collected Essays (New York, Library of America, 1998), pp. 780-3.

Bambara, Toni Cade, These Bones Are Not My Child (London, Women's Press, 2001).

Buck-Morss, Susan, Thinking Past Terror. Islamism and Critical Theory on the Left

(London, Verso, 2006). 

2009).

Champion, Ernest A., Mr. Baldwin, I Presume (Lanham, Maryland, University Press of America, 1995).

Cohen, Stanley, States of Denial: Knowing About Atrocities and Suffering (Cambridge, Polity, 2000).

Deleuze, Gilles and Guattari, Félix. Kafka, Towards a Minor Literature (Minneapolis, University of Minnesota Press, 1986).

Fanon, Frantz, The Wretched of the Earth (Hardmonsworth, Penguin, 1971).

Gikandi, Simon, Reading Chinua Achebe (London, James Currey, 1991).

"Fifty Years of Things Fall Apart," Wasafiri, 24:3 (2009), pp. 4-7.

"Afro-Victorian Worlds," in Martin Hewitt (ed.), The Victorian World (Abingdon, Routledge, 2012), pp. 671-90.

Hall, Stuart and Scott, David, "In Conversation," Bomb, 90 (2005), http://bombmagazine. org/issues/90 (accessed 13 May 2016).

House, Jim and MacMaster, Neil, Paris 1961: Algerians, State Terror, and Memory (Oxford, Oxford University Press, 2006).

Innes, C. L., Chinua Achebe (Cambridge, Cambridge University Press, 1992).

James, C. L. R., The Black Jacobins: Toussaint L'Ouverture and the San Domingo Revolution (London, Allison and Busby, 1991).

Jones, Tayari, Leaving Atlanta (New York, Warner Books, 2002).

Kaplan, Cora and Schwarz, Bill, "Baldwin: America and Beyond," in Cora Kaplan and Bill Schwarz (eds.), James Baldwin: America and Beyond (Ann Arbor, University of Michigan Press, 2011), pp. 1-32.

- (eds.), James Baldwin. America and Beyond (Ann Arbor, University of Michigan Press, 2011).

King, Martin Luther, Jr., "Letter from Birmingham Jail," in Why We Can't Wait (New York, Signet, 2000), pp. 85-110.

"The Negro Revolution," in Why We Can't Wait (New York, Signet, 2000), pp. 5-20.

Phillips, Caryl, "James Baldwin. The Price of the Ticket," in Colour Me English: Reflections on Migration and Belonging (London, Harvill Secker, 2011), pp. 239-50.

Randall-Tsuruta, Dorothy, "In Dialogue to Define Aesthetics: James Baldwin and Chinua Achebe," in Fred L. Stanley and Louis H. Pratt (eds.), Conversations with James Baldwin (Jackson, University Press of Mississippi, 1989), pp. 210-21.

Reid-Pharr, Robert, "Rendezvous with Life. Reading Early and Late Baldwin," in Cora Kaplan and Bill Schwarz (eds.), James Baldwin. America and Beyond (Ann Arbor, University of Michigan Press, 2011), pp. 126-38.

Schwarz, Bill, "Black America and the Overthrow of the European Colonial Order. The Tragic Voice of Richard Wright," in Ruth Craggs and Claire Wintle (eds.), Cultures of Decolonisation (Manchester, Manchester University Press, 2016), Forthcoming.

Scott, David, Conscripts of Modernity. The Tragedy of Postcolonial Enlightenment (Durham, Duke University Press, 2004).

Soyinka, Wole, Climate of Fear. The Reith Lectures 2004 (London, Profile, 2004).

Traylor, Eleanor W., "James Baldwin and Chinua Achebe. Transgressing Official Vocabularies," in Cora Kaplan and Bill Schwarz (eds.), James Baldwin: America and Beyond (Ann Arbor, University of Michigan Press, 2011), pp. 229-40. 
Wright, Richard, Black Power: Three Books from Exile. Black Power; The Color Curtain; and White Man, Listen! (New York, HarperPerennial, 2008).

Young, Robert J. C., "World Literature and Postcolonialism," in Theo D'haen, David Damrosch and Djelal Kadir (eds.), The Routledge Companion to World Literature (Abingdon, Routledge, 2011), pp. 213-22.

\section{Contributor's Biography}

Bill Schwarz teaches Caribbean literature in the School of English and Drama, Queen Mary University of London. He is currently completing the second of his three-volume history, Memories of Empire (Oxford University Press). In 2015-16 he will be at the National Humanities Center, preparing Stuart Hall's manuscripts for publication. 